\title{
Seasonal variation in ground water quality and its suitability for drinking and agriculture -a case study in Kancheepuram region, Tamil Nadu, India
}

\author{
Arivarasi $\mathbf{R}^{*}$ and Ganesan $\mathbf{M}$. \\ Centre for Water Resources, Department of Civil Engineering, Anna University, Chennai- 25, \\ Received: 24/04/2015, Accepted: 07/03/2017, Available online: 23/03/2017 \\ *to whom all correspondence should be addressed: \\ e-mail: arivarasi.tvr@gmail.com
}

\begin{abstract}
In the present study an attempt has been made to assess the seasonal ground water quality variations at Kancheepuram region, Tamil Nadu, India. In order to evaluate the seasonal ground water quality for drinking and irrigation purposes, 68 groundwater well data were collected and analyzed for various physico-chemical parameters such as electrical conductivity (EC), $\mathrm{pH}$, total dissolved solids (TDS), total hardness (TH), $\mathrm{Na}^{+}, \mathrm{Ca}^{2+}, \mathrm{Mg}^{2+}$, $\mathrm{Cl}^{-}, \mathrm{SO}_{4}{ }^{2-}, \mathrm{HCO}_{3}{ }^{-}$and $\mathrm{F}^{-}$. Nine parameters viz., $\mathrm{pH}, \mathrm{TDS}, \mathrm{TH}$, $\mathrm{Ca}^{2+}, \mathrm{Mg}^{2+}, \mathrm{Cl}^{-}, \mathrm{SO}_{4}{ }^{2-}, \mathrm{HCO}_{3}{ }^{-}$and $\mathrm{F}^{-}$were used to calculate the Water Quality Index (WQI) using weighted arithmetic index for drinking purpose. EC and Sodium Adsorption Ratio (SAR) were the two important indicators used to assess the irrigation water quality. Mapping was done to examine the spatial distribution of water quality parameters using Geographical Information System (GIS). From the analysis, more than half of the samples record good water quality whereas only $1 \%$ falls under unsuitable category for drinking purpose. Approximately 33\% of samples falls under poor quality for drinking. In terms of irrigation, the salinity hazard occurs in 23 to $42 \%$ of sampling locations depicting the uncertainty towards agricultural production in the study region. From the study, it is observed that the water quality is highly degraded where Industrialization and urbanization took place when compared to areas where agriculture is being practiced. Hence, suitable measures to ameliorate the pollution effect of urbanization and industrializations are suggested.
\end{abstract}

Keywords: irrigation, physico-chemical, sodium hazard, sodium adsorption ratio, water quality index,

\section{Introduction}

Water is one of the most essential natural resources for all life on Earth, playing a major role in a country's economic development. Groundwater forms the major source of water supply for drinking, domestic, agricultural and industrial uses in India. Due to industrialization and urbanization the usage of ground water has considerably increased in those areas. It leads to over exploitation of groundwater and sea water intrusion in the coastal zones where urbanization is taking place at an accelerated rate. The water quality deterioration is the main cause of sea water intrusion (Srikanthan et al., 2013). Among the many factors affecting the groundwater quality, ground water interaction with earth soil and rocks is one of the important factors. The poor ground water quality affects the plant growth and human health. Groundwater chemistry based on hydro chemical data is useful for providing preliminary information on water types, classification of water for various purposes as well as for identification of different types of groundwater aquifers and study of different chemical processes (Karanth, 1987). Urbanization, industrialization and the unregulated growth of the population have altered the landscape of many urban and peri-urban areas. Changes in land use pattern, local topography and drainage systems directly affect both quality and quantity of groundwater. Inadequate environmental protection measures in the industrial and peri-urban areas coupled with dumping of solid and liquid wastes in the natural river course and water bodies have resulted in significant water pollution in Kancheepuram region. Rapid urbanization has affected the groundwater quantity; over exploitation and improper waste disposal have affected the quality of water. If the quality of groundwater is once contaminated, it is not possible to restore to its original quality. Regular monitoring of groundwater is important to protect their quality from the pollution (Ramakrishnaiah et al., 2009).

Water pollution not only affects water quality but also cause threats to human health, economic development and social well-being. Groundwater aquifers are highly vulnerable to pollution due to recharging of domestic, industrial and agricultural waste water; therefore, it is significant to control water pollution and monitor water quality.

Various geo-statistical concepts were used for the interpretation of complex ground water data sets which allows a better understanding of the water quality parameters. Groundwater chemistry has been utilized as a tool to investigate water quality for various purposes. WQI is an important technique for demarcating groundwater 
quality and its suitability for drinking purposes. WQI is defined as a technique of rating that provides the composite influence of individual water quality parameters on the overall quality of water for human consumption. WQI is a mathematical equation used to transform large number of water quality parameters into a single number. It is simple and easy to understand for decision makers since it integrates complex parameters and generates a score that describe the water quality status.

In earlier water quality studies, a number of grouped parameters were investigated to ascertain the water quality; the drinking water quality was also assessed by means of WQI; It is calculated from the relative weight of physico-chemical and biological properties present in the water such as $\mathrm{pH}, \mathrm{EC}, \mathrm{TDS}, \mathrm{TH}\left(\mathrm{CaCO}_{3}\right)$, alkalinity, total suspended solids (TSS), calcium, magnesium, chloride, nitrate, sulphate, dissolved oxygen (DO) and bio-chemical oxygen demand (BOD) (Yogendra and Puttaiah 2008; Basavareddi et al., 2012; Srikanthan et al., 2013; Manju et al., 2014; Shobana et al., 2014; Upadhyay and Chandrakala, 2014 ). In addition to the above parameters, additional parameters are also added to the groups: the added parameters are: temperature, free $\mathrm{CO}_{2}, \mathrm{COD}$, carbonate, bicarbonate, turbidity, sodium, potassium and phosphate (Joshi et al., 2009), iron, manganese and fluorides (Ramakrishnaiah et al., 2009; Kalra et al. 2012; Tambekar et al. 2012), ammonia, hexavalent chromium, heavy metals (Govindarajan and Senthilnathan, 2014), fecal coliform (Kankal et al., 2012), acidity, boron and salinity (Rupal et al., 2012).

The irrigation water quality was analyzed based on temperature, $\mathrm{pH}, \mathrm{EC}, \mathrm{Cl}^{-}$, sodium percent (\%Na), SAR, TH, TDS, soluble sodium percentage (SSP), exchangeable sodium percentage (ESP), residual sodium carbonate(RSC), Kelly's ratio (Camberato, 2001; Islam and Shamsad, 2009; Omran et al., 2014). The following additional parameters were also used for classifying irrigation water quality: Permeability index (PI) (Haque, 2009), Scheller's (Chloroalkaline) index, Magnesium and salinity hazard, Mineral saturation (Abdullahi et al., 2010), $\mathrm{HCO}_{3}$ (Ghislain et al., 2012) and magnesium adsorption ratio (MAR), (Venkateswaran and Vediappan, 2013; Nag and Das, 2014).

A number of studies on groundwater quality with respect to drinking and irrigation purposes have also been carried out in Kancheepuram District at different times. The results are not comparable mainly due to temporal variation that had occurred due to continuous increase in urbanization and industrialization resulting in increased extraction of groundwater for irrigation, industries and domestic uses. Added to these, the pollution caused due to inadequate drainage facilities and dumping of solid and liquid wastes in open access area has affected the groundwater quality.

In this study, the detailed hydro-chemical study was carried out to evaluate the groundwater quality for drinking and irrigation purposes and how it meets the water quality standards within the study area. Based on the status, certain alternative measures for improving water quality are also suggested.

\section{Study Area}

Kancheepuram region is one of the most urbanized districts in Tamil Nadu state which is in the southern part of India. The geographical area of the region is about $4433 \mathrm{~km}^{2}$ and its water resources are utilized for multi-purposes such as drinking, industrial and irrigation use. The district has been divided into four revenue divisions comprising 11 taluks with 1137 revenue villages. For development purposes, it is divided into 13 blocks with 648 village panchayats. The district receives rain under the influence of both south west (June - August) and north east (September - November) monsoons. Most of the precipitation occurs in the form of cyclonic storm caused due to depression in the Bay of Bengal mainly during the north east monsoon period. The south west monsoon rainfall is highly erratic and summer (April - May) rains are negligible. The minimum and maximum temperatures are $20^{\circ} \mathrm{C}$ and $37^{\circ} \mathrm{C}$ respectively. The day time heat is oppressive and the temperature will reach as high as $43^{\circ} \mathrm{C}$ during summer.

\subsection{Industrial scenario}

Kancheepuram district is known for its paddy and pulses cultivation. There are large number of energy food manufacturing units for all age groups and rice mills. Traditional industries like handloom, silk weaving and rice milling are concentrated in Kancheepuram and Maduranthagam blocks. Nowadays, the district having number of small to large scale industries, information technology park, auto mobile companies, refineries, treatment plants, dumping yards. There are large scale units have come up recently for two and four wheeler automobiles in Sriperumpudur and Kattankolathur block and giant glass manufacturing unit of Saint Gohain glass factory near Sriperumpudur. Small Scale Industrial units exist in St.Thomas Mount, Kancheepuram and Kattankulathur blocks. Under such vast developmental activities, obviously the quality and quantity of water resources are getting reduced and polluted without adequate safeguard measures. For this study, the 13 blocks are grouped into 3 broad categories namely Agriculture based (Acharapakkam, Chittamur, Cheyyur, Thirukalukundram and Thiruporur blocks), Urbanized (Kancheepuram, Kundrathur, Maduranthagam and Uthiramerur) and Industrialized (Kattankolathur, St Thomas Mount, Sriperumbadur and Walajabad) and analyzed.

\section{Methodology}

First, an attempt has been made to understand the drinking water quality status using Water Quality Index (WQI) and Irrigation water quality in three regions of Kancheepuram District. WQI, a technique to measure water quality, is an effective tool to assess spatial and temporal changes in ground water quality. For this, the groundwater sample data from 68 wells were collected for pre and post monsoon season and analyzed for physical and chemical parameters.

There are three steps for computing WQI. In the first step, each of nine parameters $\left(\mathrm{pH}, \mathrm{TDS}, \mathrm{TH}\right.$, calcium $\left(\mathrm{Ca}^{2+}\right)$, 
magnesium $\left(\mathrm{Mg}^{2+}\right)$, chloride $\left(\mathrm{Cl}^{-}\right)$, sulfates $\left(\mathrm{SO}_{4}{ }^{2-}\right)$, bicarbonate $\left(\mathrm{HCO}_{3}{ }^{-}\right)$and fluoride $\left.\left(\mathrm{F}^{-}\right)\right)$has been assigned a weight $\left(\mathrm{W}_{\mathrm{i}}\right)$ according to its relative importance in the overall quality of water for drinking purpose (Table 1). For $\mathrm{pH}, \mathrm{TDS}, \mathrm{SO}_{4}{ }^{2-}$ and $\mathrm{F}^{-}$the highest weight was assigned as 4; for $\mathrm{Cl}^{-}$and $\mathrm{HCO}_{3}{ }^{-}$, it was assigned 3 and for the remaining parameters such as $\mathrm{TH}, \mathrm{Ca}^{2+}$ and $\mathrm{Mg}^{2+}$ an assigned weight is 2 .

The WQI has been calculated using weighted arithmetic index method (Rupal et al., 2012) and compared with standards of drinking water quality recommended by the World Health Organization, Bureau of Indian Standards (BIS), Indian Standards (IS) and Indian Council for Medical Research (ICMR). Equation 1 shows the formula used for WQI calculation.

$$
\text { WQI }=W_{i}=w_{i} \div \sum_{i=1}^{n} w_{i}
$$

Where, $W_{i}$ - relative weight, $W_{i}$ - weight of each parameter and $n$ - number of parameters. Weight $\left(w_{i}\right)$ for each parameter was taken from the literature (Ramakrishnaiah et al., 2009).

The irrigation water quality has been evaluated based on EC and SAR (Aghazadeh and Mogaddam, 2010). The formula used to calculate SAR is shown in the equation 2. Mapping has been done in ArcGIS 10 environment to find the spatial distribution of drinking and irrigation water quality for pre and post monsoon season.

$$
\mathrm{SAR}=\mathrm{Na} /(\mathrm{V}((\mathrm{Ca}+\mathrm{Mg}) / 2))
$$

The statistical analysis such as arithmetic mean (AM), median, standard deviation (SD) relative standard deviation (RSD) and correlation coefficient matrix has been done to identify the existing scenario of hydro physicochemical properties using Microsoft Excel environment. To find the significant level, student's t test was carried out. The location map of sampling wells is shown in Figure 1.
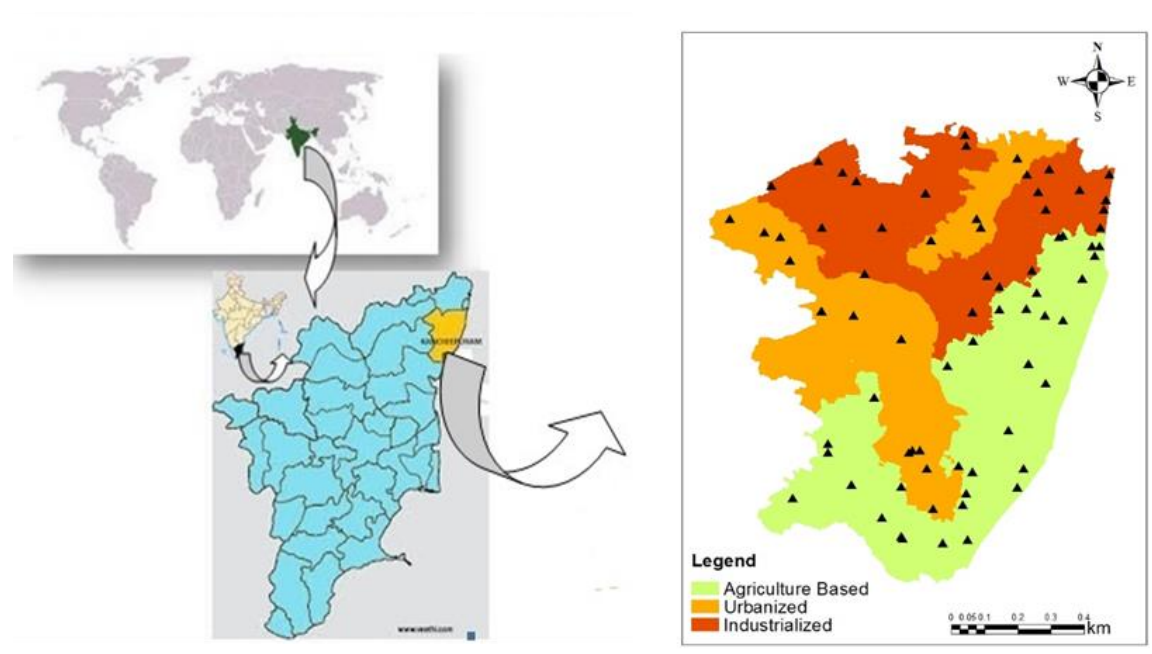

Figure 1. Location Map of groundwater sample wells in Kancheepuram region

Table 1. Relative weight (Wi) of each physico-chemical parameter (All values except $\mathrm{pH}$ are in $\mathrm{mg} \mathrm{l}^{-1}$ )

\begin{tabular}{ccccc}
\hline Parameters & Standards & Recommended Agency & Weight $\left(\mathbf{w}_{\mathbf{i}}\right)$ & Relative $\mathbf{W e i g h t}_{(\mathbf{W})}$ \\
\hline $\mathrm{pH}$ & $6.5-8.5$ & ICMR/BIS & 4 & 0.143 \\
\hline $\mathrm{TDS}$ & 500 & ICMR/BIS & 4 & 0.143 \\
\hline $\mathrm{TH}$ & 300 & ICMR/BIS & 2 & 0.071 \\
\hline $\mathrm{Ca}^{2+}$ & 75 & $\mathrm{ICMR} / \mathrm{BIS} / \mathrm{WHO}$ & 0.071 \\
\hline $\mathrm{Mg}^{2+}$ & 30 & $\mathrm{ICMR} / \mathrm{BIS} / \mathrm{WHO}$ & 0.071 \\
\hline $\mathrm{Cl}^{-}$ & 250 & $\mathrm{ICMR} / \mathrm{WHO}$ & 2 & 0.107 \\
\hline $\mathrm{SO}_{4}{ }^{2-}$ & 200 & $\mathrm{WHO}$ & 3 & 0.143 \\
\hline $\mathrm{HCO}_{3}{ }^{-}$ & $244-732$ & $\mathrm{IS}$ & 4 & 0.107 \\
\hline $\mathrm{F}^{-}$ & 1 & $\mathrm{WHO}$ & 3 & 0.143 \\
\hline
\end{tabular}

\section{Results and discussion}

\subsection{Statistical Analysis of Hydro-Chemical Data}

The statistics of water quality parameters obtained during pre and post monsoon season are shown in Tables 2 and 3. From the Tables, it is observed that there is no remarkable variation in the mean values of seasonal water quality parameters such as $\mathrm{pH}, \mathrm{Mg}$ and $\mathrm{F}^{-}$. When compared to the pre monsoon, $\mathrm{TH}, \mathrm{Ca}^{2+}$ and $\mathrm{HCO}_{3}{ }^{-}$have increased and TDS, $\mathrm{Cl}^{-}$and $\mathrm{SO}_{4}{ }^{2-}$ have decreased during post monsoon season. In some locations, the maximum values of the parameters such as $\mathrm{pH}, \mathrm{TDS}, \mathrm{TH}, \mathrm{Ca}^{2+}, \mathrm{Mg}^{2+}$, and $\mathrm{SO}_{4}{ }^{2-}$ are exceeding the 
permissible limit. The standard deviation is also high for all the parameters except $\mathrm{pH}$ and $\mathrm{F}^{-}$. For $\mathrm{pH}, 22 \%$ and $16 \%$ of sampled data exceed the permissible limit during post and pre monsoon respectively. For TDS and $\mathrm{TH}$, in both the season only $1 \%$ of sample exceeds the limit and for $\mathrm{Ca}^{2+}$, $\mathrm{Mg}^{2+}$ and $\mathrm{SO}_{4}{ }^{2-}$ during post monsoon, $3-6 \%$ and for pre monsoon around $1-3 \%$ of sample exceeds the permissible limit. From the analysis it is identified that during pre and post monsoon season, the water quality is poor in the areas such as Salaiyur (Maduranthagam taluk), Pondur and Madambakkam (Sriperumbudur taluk) and not suitable for drinking. Salaiyur comes under the urbanized zone whereas Pondur and Madambakkam come under the industrial zone.

Table 2. Statistical analysis for Pre monsoon

\begin{tabular}{ccccccc}
\hline Parameters & MEDIAN & MIN & MAX & SD & AM & RSD \\
\hline pH & 8.20 & 7.60 & 8.90 & 0.27 & 8.27 & 3 \\
\hline TDS & 554.50 & 147.00 & 2412.00 & 386.96 & 636.14 & 60 \\
\hline Total Hardness & 170.00 & 60.00 & 670.00 & 118.17 & 211.29 & 56 \\
\hline $\mathbf{C a}^{2+}$ & 43.00 & 8.00 & 288.00 & 45.28 & 53.29 & 85 \\
\hline $\mathbf{M g}^{2+}$ & 32.81 & 6.08 & 111.78 & 23.14 & 38.38 & 60 \\
\hline $\mathbf{C l}^{-}$ & 133.00 & 18.00 & 908.00 & 164.13 & 187.41 & 87 \\
\hline $\mathbf{S O}_{4}{ }^{2-}$ & 40.50 & 3.00 & 864.00 & 108.76 & 67.61 & 160 \\
\hline $\mathbf{H C O}_{3}{ }^{-}$ & 172.50 & 48.80 & 683.20 & 130.32 & 209.40 & 62 \\
\hline $\mathbf{F}^{-}$ & 0.3 & 0.09 & 0.94 & 0.22 & 0.38 & 59 \\
\hline
\end{tabular}

(Total number of sample $\mathrm{N}=70$ )

Table 3. Statistical analysis for Post monsoon

\begin{tabular}{ccccccc}
\hline Parameters & MEDIAN & MIN & MAX & SD & AM & RSD \\
\hline pH & 8.40 & 7.70 & 9.00 & 0.31 & 8.36 & 3.67 \\
\hline TDS & 476.00 & 158.00 & 2373.00 & 396.86 & 610.07 & 65 \\
\hline Total Hardness & 187.50 & 90.00 & 640.00 & 110.35 & 217.43 & 51 \\
\hline $\mathbf{C a}^{2+}$ & 47.00 & 8.00 & 328.00 & 48.44 & 60.28 & 80 \\
\hline $\mathbf{~ M g}^{2+}$ & 27.34 & 6.08 & 140.94 & 28.96 & 37.20 & 78 \\
\hline $\mathbf{C l}^{-}$ & 108.00 & 18.00 & 1219.00 & 190.41 & 166.54 & 114 \\
\hline $\mathbf{S O}_{4}{ }^{2-}$ & 43.50 & 2.00 & 504.00 & 72.38 & 63.75 & 113 \\
\hline $\mathbf{H C O}_{3}{ }^{-}$ & 180.07 & 85.40 & 610.00 & 117.09 & 222.36 & 52 \\
\hline $\mathbf{F}^{-}$ & 0.21 & 0.10 & 1.10 & 0.23 & 0.31 & 74 \\
\hline
\end{tabular}

(Total number of sample $\mathrm{N}=68$ )

Table 4. Correlation co-efficient matrix for Post monsoon

\begin{tabular}{cccccccccc}
\hline Parameters & $\mathbf{p H}$ & $\mathbf{T D S}$ & $\mathbf{T H}$ & $\mathbf{C a}^{2+}$ & $\mathbf{M g}^{2+}$ & $\mathbf{C l}^{-}$ & $\mathbf{S O}_{4}{ }^{2-}$ & $\mathbf{H C O}_{3}{ }^{-}$ & $\mathbf{F}$ \\
\hline $\mathbf{p H}$ & 1 & -0.234 & 0.285 & -0.357 & -0.310 & -0.401 & -0.155 & 0.138 & 0.113 \\
\hline $\mathbf{T D S}$ & -0.234 & 1 & 0.331 & 0.728 & 0.793 & 0.894 & 0.806 & 0.398 & 0.205 \\
\hline $\mathbf{T H}$ & 0.285 & 0.331 & 1 & -0.241 & 0.027 & -0.052 & 0.078 & 0.975 & 0.628 \\
\hline $\mathbf{C a}^{2+}$ & -0.357 & 0.728 & -0.241 & 1 & 0.691 & 0.865 & 0.664 & -0.184 & -0.165 \\
\hline $\mathbf{M g}^{2+}$ & -0.310 & 0.793 & 0.027 & 0.691 & 1 & 0.838 & 0.691 & 0.110 & 0.055 \\
\hline $\mathbf{C l}^{-}$ & -0.401 & 0.894 & -0.052 & 0.865 & 0.838 & 1 & 0.682 & 0.040 & 0.001 \\
\hline $\mathbf{S O}_{4}{ }^{2-}$ & -0.155 & 0.806 & 0.078 & 0.664 & 0.691 & 0.682 & 1 & 0.122 & 0.014 \\
\hline $\mathbf{H C O}_{3}{ }^{-}$ & 0.138 & 0.398 & 0.975 & -0.184 & 0.110 & 0.040 & 0.122 & 1 & 0.636 \\
\hline $\mathbf{F}^{-}$ & 0.113 & 0.205 & 0.628 & -0.165 & 0.055 & 0.001 & 0.014 & 0.636 & 1 \\
\hline
\end{tabular}

Correlation coefficients $(r)$ for different parameters were determined for Pre and Post monsoon seasons. Table 4 and 5 show the correlation coefficient matrix of important water quality parameters for both the seasons. The $r$ value is indicative of degree of a linear relationship between any two of the parameters. From the table, $r \geq 0.06$ gives a greater degree of correlation. The highest correlation was found among (i) In Post monsoon season: TDS against $\mathrm{Ca}^{2+}$, $\mathrm{Mg}^{2+}, \mathrm{Cl}^{-}$and $\mathrm{SO}_{4}{ }^{2-} \mathrm{TH}$ against $\mathrm{HCO}_{3}{ }^{-}$and $\mathrm{F}^{-} ; \mathrm{Ca}^{2+}$ against $\mathrm{Mg}^{2+}, \mathrm{Cl}^{-}$and $\mathrm{SO}_{4}{ }^{2-} \mathrm{Mg}^{2+}$ against $\mathrm{Cl}^{-}$and $\mathrm{SO}_{4}{ }^{2-} ; \mathrm{Cl}^{-}$against
$\mathrm{SO}_{4}{ }^{2-}, \mathrm{HCO}_{3}{ }^{-}$and $\mathrm{F}^{-}$and (ii) In Pre monsoon season: TDS against $\mathrm{Ca}^{2+}, \mathrm{Mg}^{2+}, \mathrm{Cl}^{-}$and $\mathrm{SO}_{4}{ }^{2} ; \mathrm{TH}$ against $\mathrm{HCO}_{3}{ }^{-} ; \mathrm{Ca}^{2+}$ against $\mathrm{Cl}^{-}$and $\mathrm{SO}_{4}{ }^{2-}$. The above results indicate that there is a very high correlation of TDS, $\mathrm{TH}, \mathrm{Ca}^{2+}, \mathrm{Mg}^{2+}$ and $\mathrm{Cl}^{-}$with other parameters while in pre monsoon period such high correlations among the various parameters does not exist. One of the reasons for this high correlation is due to polluted water from the industrialized and urbanized area is being recharged during the post monsoon season. 
Table 5. Correlation co-efficient matrix for Pre monsoon

\begin{tabular}{cccccccccc}
\hline Parameters & $\mathbf{p H}$ & $\mathbf{T D S}$ & $\mathbf{T H}$ & $\mathbf{C a}^{2+}$ & $\mathbf{M g}^{2+}$ & $\mathbf{C l}^{-}$ & $\mathbf{S O}_{4}{ }^{2-}$ & $\mathbf{H C O}_{3}{ }^{-}$ & $\mathbf{F}$ \\
\hline $\mathbf{p H}$ & 1 & -0.085 & 0.231 & -0.310 & -0.156 & -0.232 & -0.002 & -0.084 & 0.306 \\
\hline $\mathbf{T D S}$ & -0.085 & 1 & 0.326 & 0.712 & 0.716 & 0.873 & 0.702 & 0.351 & 0.082 \\
\hline $\mathbf{T H}$ & 0.231 & 0.326 & 1 & -0.165 & 0.007 & -0.045 & -0.010 & 0.908 & 0.358 \\
\hline $\mathbf{C a}^{2+}$ & -0.310 & 0.712 & -0.165 & 1 & 0.550 & 0.763 & 0.627 & -0.092 & -0.250 \\
\hline $\mathbf{M g}^{2+}$ & -0.156 & 0.716 & 0.007 & 0.550 & 1 & 0.744 & 0.539 & 0.047 & 0.012 \\
\hline $\mathbf{C l}^{-}$ & -0.232 & 0.873 & -0.045 & 0.763 & 0.744 & 1 & 0.514 & 0.029 & -0.024 \\
\hline $\mathbf{S O}_{4}{ }^{2-}$ & -0.002 & 0.702 & -0.010 & 0.627 & 0.539 & 0.514 & 1 & 0.011 & -0.049 \\
\hline $\mathbf{H C O}_{3}{ }^{-}$ & -0.084 & 0.351 & 0.908 & -0.092 & 0.047 & 0.029 & 0.011 & 1 & 0.332 \\
\hline $\mathbf{F}$ & 0.306 & 0.082 & 0.358 & -0.250 & 0.012 & -0.024 & -0.049 & 0.332 & 1 \\
\hline
\end{tabular}

From the statistical significance test, it was identified that all the parameters in both pre and post monsoon seasons are equal at $5 \%$ significance level.

\subsection{Water Quality Index for Drinking}

Water Quality Index was calculated based on the relative weight of each physico-chemical parameter. The values of WQI of the samples were found in the range of 27-114 in post-monsoon season while it was $26-131$ in the premonsoon season.

Figure 2 depicts the spatial distribution of WQI for the post and pre monsoon seasons. Table 6 represents the classification of ground water based on WQI. It is clear that,

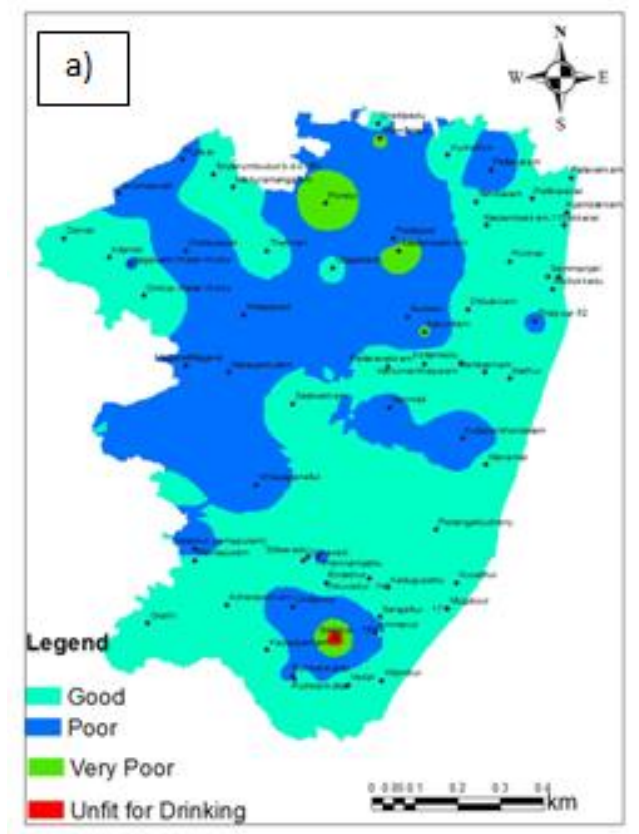

66 and $60 \%$ of sampling locations fall under good category for drinking during post and pre monsoon respectively. The results also indicate $33 \%(27 \%+6 \%)$ and $39 \%(36 \%+3 \%)$ are having poor water quality during post and pre monsoon respectively. Only $1 \%$ falls under not suitable category (part of Maduranthagam block (Post monsoon) and Sriperumbudur block (Pre monsoon)) in the entire study region. The block wise villages which affected during monsoon were tabulated (Table 7). It is identified that the area dominated with agricultural practices is highly influenced by post monsoon season whereas the urbanized and industrialized areas were affected during both the seasons.

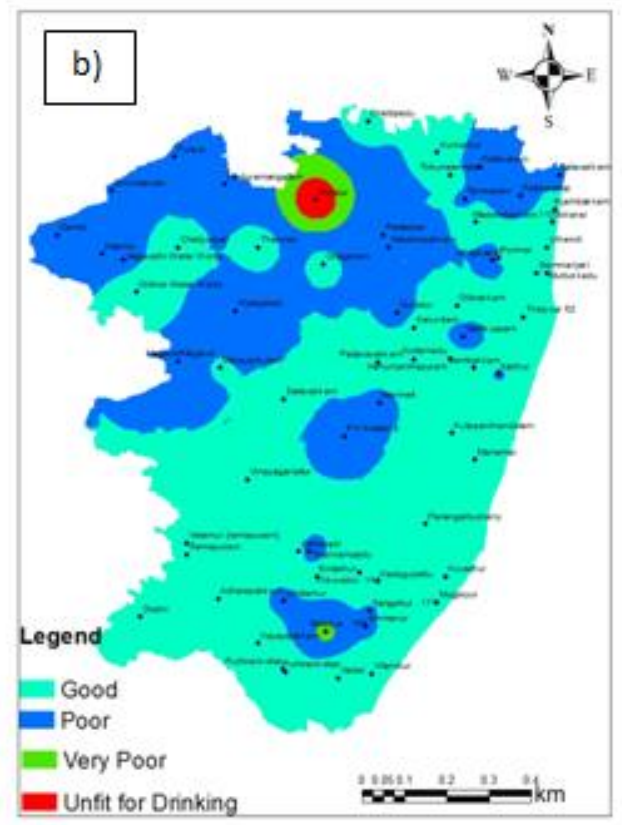

Figure 2. Spatial distribution of WQI - a) Post monsoon b) Pre monsoon

Table 6. Classification of Groundwater for Drinking Purpose based on WQI

\begin{tabular}{cccc}
\hline WQI Value & Water Quality & $\begin{array}{c}\text { Percent of Sampling locations } \\
\text { (Post monsoon) }\end{array}$ & $\begin{array}{c}\text { Percent of Sampling locations } \\
\text { (Pre monsoon) }\end{array}$ \\
\hline $0-25$ & Excellent & 0 & 0 \\
\hline $25-50$ & Good & 66 & 60 \\
\hline $50-75$ & Poor & 27 & 36 \\
\hline $75-100$ & Very poor & 6 & 3 \\
\hline$>100$ & Unfit for drinking & 1 & 1 \\
\hline
\end{tabular}


Table 7. Block wise water quality status during Post and Pre monsoon season

\begin{tabular}{|c|c|c|c|c|}
\hline \multirow{2}{*}{ SI NO } & \multirow{2}{*}{ Block } & \multicolumn{3}{|c|}{ Villages } \\
\hline & & Poor & Very poor & Unfit for drinking \\
\hline \multirow[t]{3}{*}{1} & \multicolumn{4}{|c|}{ Acharapakkam (Highly influenced by Post monsoon) } \\
\hline & Post Monsoon & Velamur, Vinayaganallur & NA & NA \\
\hline & Pre Monsoon & NA & NA & NA \\
\hline \multirow[t]{3}{*}{2} & Chittamur (High & ed by Post monsoon) & & \\
\hline & Post Monsoon & $\begin{array}{l}\text { Chittamur, Vilangad, Puthiran kottai, } \\
\text { Amandankarunai }\end{array}$ & NA & NA \\
\hline & Pre Monsoon & $\begin{array}{l}\text { Chittamur, Vilangadu, } \\
\text { Kannimangalam }\end{array}$ & NA & NA \\
\hline 3 & \multicolumn{4}{|c|}{ Kancheepuram (Highly influenced by Pre monsoon) } \\
\hline & Post Monsoon & $\begin{array}{l}\text { Vegavathi, Magaral, Konerikuppam, } \\
\text { Nathapettai }\end{array}$ & NA & NA \\
\hline & Pre Monsoon & $\begin{array}{l}\text { Damal, Kilambi, Vegavathi, Vathiyur, } \\
\text { Ariaperumbakkam, Sadathangal, } \\
\text { Magaral, Nelveli, Melputtur, Kilputtu }\end{array}$ & NA & NA \\
\hline
\end{tabular}

$4 \quad$ Kattankulathur (Highly influenced by Post monsoon)

\begin{tabular}{|c|c|c|c|c|}
\hline 5 & $\begin{array}{l}\text { Pre Monsoon } \\
\text { Kundrathur (Hig }\end{array}$ & $\begin{array}{l}\text { Gudalur, Urapakkam, Guduvanchery, } \\
\text { Nandivaram, Kayaranmeedu, } \\
\text { Thirukatchur } \\
\text { Gudalur, Urapakkam, Peramanur, } \\
\text { Panangottur, Kolapakkam, Potheri, } \\
\text { Guduvanchery, } \\
\text { ed by Post monsoon) }\end{array}$ & Karunilam & NA \\
\hline & Post Monsoon & $\begin{array}{l}\text { Padappai, Vaipoor, Salamangalam, } \\
\text { Manimangalam, } \\
\text { Padappai, Orathur, Madambakkam, } \\
\text { Kanchivakkam, Karasangal, } \\
\text { Salamangalam, Manimangalam, } \\
\text { Nattarasanpattu, Naduveerapattu, }\end{array}$ & $\begin{array}{l}\text { Madambakkam, Athunur, } \\
\text { Ammanabakkam, } \\
\text { Neelamangalam }\end{array}$ & NA \\
\hline SI NO & Block & Poor & Very poor & Unfit for drinking \\
\hline 6 & \multicolumn{4}{|c|}{ Cheyyur (Similar Water Quality during Post and Pre monsoon) } \\
\hline 7 & $\begin{array}{l}\text { Post Monsoon } \\
\text { Pre Monsoon } \\
\text { Maduranthagan }\end{array}$ & $\begin{array}{l}\text { Ammanur, Maruderi } \\
\text { Ammanur, Sengattur, Maruderi } \\
\text { later Quality during Post and Pre mon }\end{array}$ & $\begin{array}{l}\text { NA } \\
\text { NA }\end{array}$ & $\begin{array}{l}\text { NA } \\
\text { NA }\end{array}$ \\
\hline 8 & $\begin{array}{l}\text { Pre Monsoon } \\
\text { St Thomas Mou }\end{array}$ & $\begin{array}{l}\text { Kattudevadur, Nallur, Neerpair, } \\
\text { Viralur, Irumbedu } \\
\text { Kattudevadur, Nallur, Irumbedu, } \\
\text { Kilavasalai, Devanur, Palayanur, } \\
\text { Thennampattu, } \\
\text { fluenced by Pre monsoon) }\end{array}$ & Budur, Kilavasalai & Salaiyur \\
\hline 9 & $\begin{array}{l}\text { Pre Monsoon } \\
\text { Sriperumbadur }\end{array}$ & $\begin{array}{l}\text { Pallavaram, Pammal, Thirisoolam } \\
\text { Palavakkam, Pallikaranai, Ullagaram, } \\
\text { Pallavaram, Thambaram, } \\
\text { Nanmangalam, Medavakkam, } \\
\text { Kovilambakkam, Palavanthangal, } \\
\text { lenced by Pre monsoon) }\end{array}$ & Karunilam & NA \\
\hline & Post Monsoon & $\begin{array}{l}\text { Valarpuram, Vengadu, } \\
\text { Irunkattukottai, Kolathur, Vellarai, } \\
\text { Sirumangadu, Vallakottai, Alagur, } \\
\text { Katrambakkam, Nallaperumbedu, } \\
\text { Kandivakkam, Mahadevi Mangalam, } \\
\text { Ramanuja puram, Madura } \\
\text { Mangalam, Santhavelur, Pennalur, } \\
\text { Keeranallur, Maganiam, }\end{array}$ & $\begin{array}{l}\text { Irungulam, Vadathanjeri, } \\
\text { Pondur, Pillaipakkam, } \\
\text { Sriperumbadur, } \\
\text { Kaduvancheri, Balanallur, } \\
\text { Sriperumbadur, Pillaipakkam, } \\
\text { Navalur, Gunduperumbedu, } \\
\text { Sirukiloy, Mambakkam, }\end{array}$ & $\begin{array}{l}\text { Irungulam, Pondur, } \\
\text { Kaduvancheri, } \\
\text { Araneri, Balanallur }\end{array}$ \\
\hline
\end{tabular}




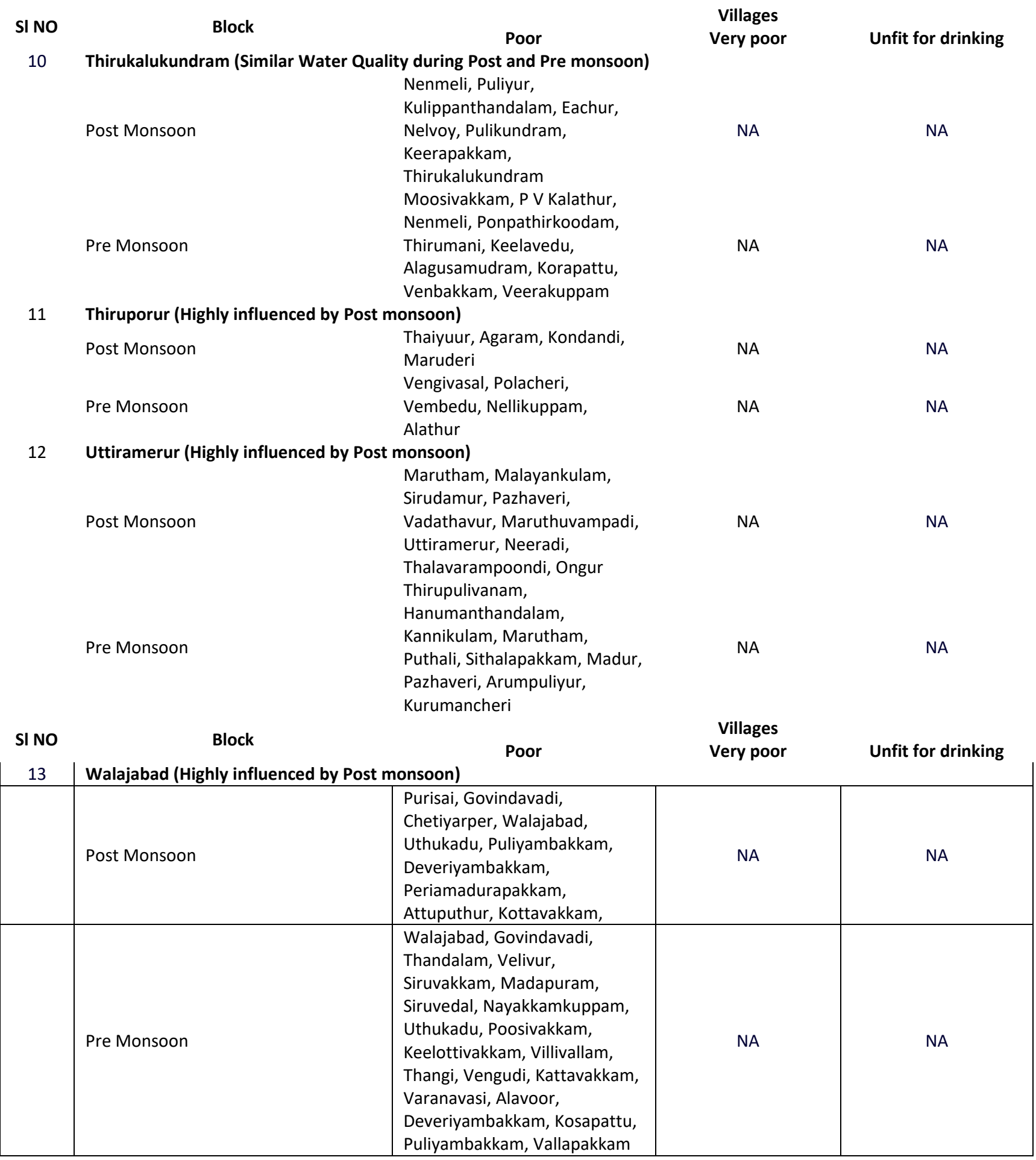

\subsection{Irrigation Water Quality}

Irrigation water quality was evaluated based on EC and SAR. In terms of EC, not even $1 \%$ of sampling location lies on an excellent category; also more than half of the locations ( $52 \%$ and $59 \%$ ) were at the doubtful category and only 28 and $26 \%$ of locations fall under the good quality during post and pre monsoon seasons respectively. During post monsoon, EC is high in Sriperumbudur, Maduranthagam, Kundrathur and St.Thomas Mount blocks. Similarly in pre monsoon, Sriperumbudur and Maduranthagam blocks have recorded higher EC. Hence, in those areas it is not advisable to irrigate salt sensitive crops using groundwater during the two seasons. The spatial distribution of EC and SAR in the study region is shown in figure 4 and 5 . From the figure 5 it is observed that the western part (urbanized and industrialized region) of the study region is having higher SAR; also the sodium hazard is high in pre monsoon rather than post monsoon season. 


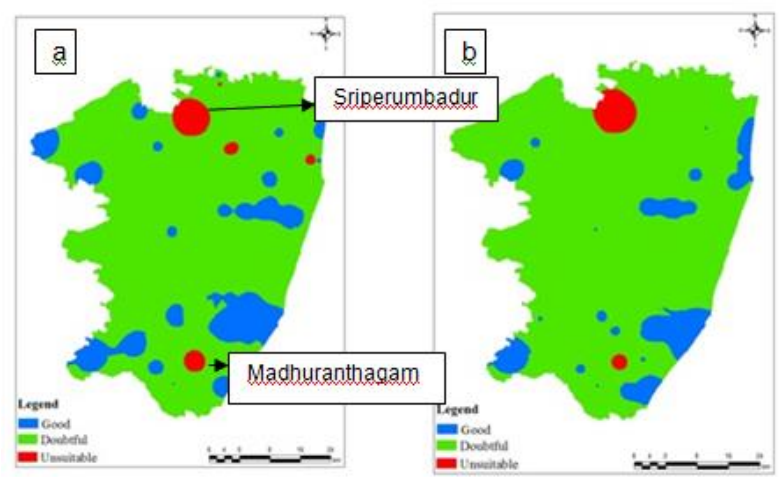

Figure 3. Spatial distribution of EC a) Post monsoon b) Pre monsoon

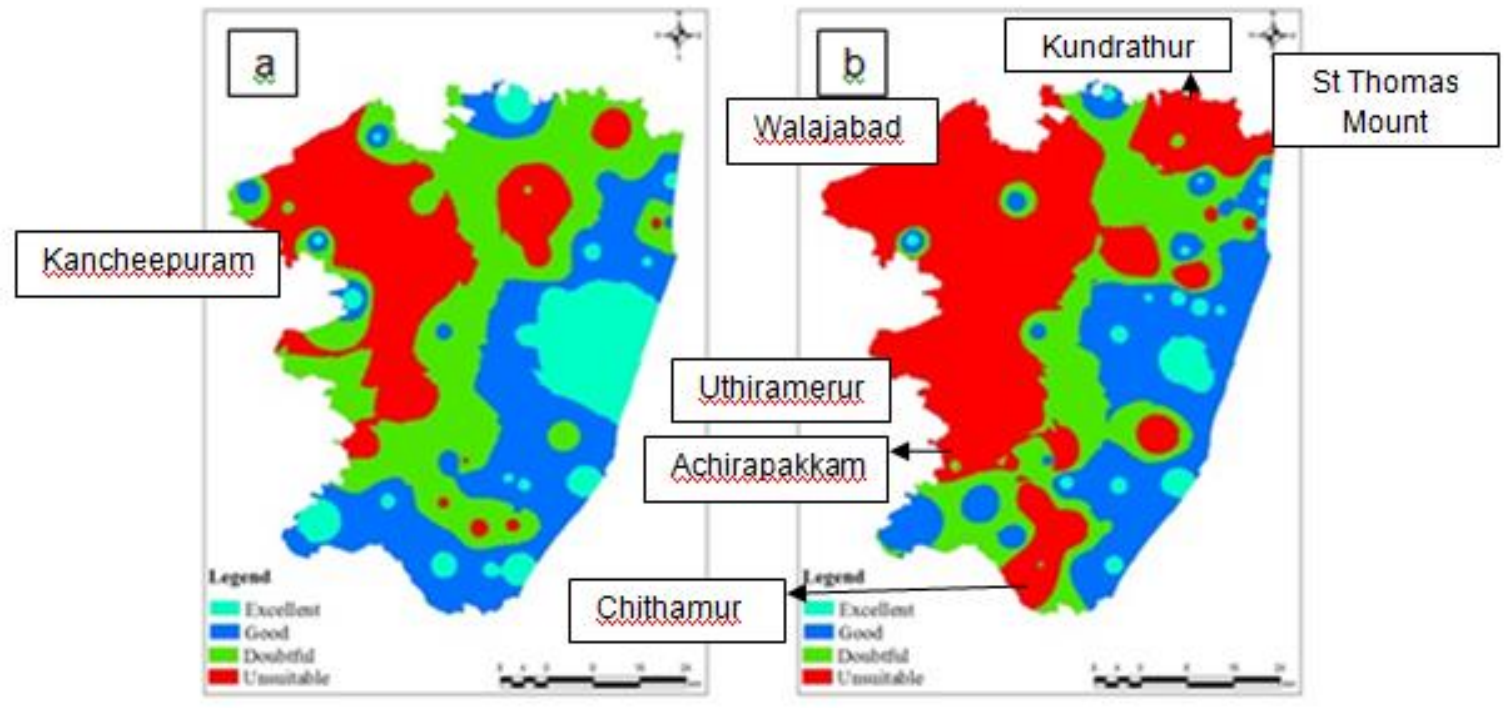

Figure 4. Spatial distribution of SAR a) Post monsoon b) Pre monsoon

Table 8. Classification of Groundwater for Irrigation based on EC, SAR

\begin{tabular}{ccc}
\hline $\begin{array}{c}\text { Quality of } \\
\text { Water }\end{array}$ & EC ( $\mu$ ohms) & $\begin{array}{c}\text { SAR (Aghazadeh N \& } \\
\text { Mogaddam A A, } \\
2010)\end{array}$ \\
\hline Excellent & $<250$ & $<10$ \\
Good & $250-750$ & $10-18$ \\
Permissible & - & - \\
Doubtful & $750-2250$ & $18-26$ \\
Unsuitable & $>2250$ & $>26$
\end{tabular}

Table 8 shows the groundwater classification limits based on EC and SAR. According to Aghazadeh \& Mogaddam standards, $35 \%$ and $27 \%$ of sampling locations during post and pre monsoon have excellent water quality and $21 \%$ of good quality to irrigate the crops during both the seasons. Also $23 \%$ and $43 \%$ of locations are not suitable for irrigation. During post monsoon season, $21 \%$ of samples fall under doubtful category whereas in pre monsoon it is only about $9 \%$. Also, SAR in post monsoon are $63 \%, 27 \%$, $4 \%$, $3 \%$ and $3 \%$ for Excellent, good, permissible, doubtful and unsuitable categories respectively while in pre monsoon the corresponding values are $49 \%, 28 \%, 17 \%, 3 \%$ and $3 \%$.

\section{Conclusions}

Water quality index is one of the most effective tools to communicate information on the quality of any water source. The physico-chemical properties of groundwater for drinking and irrigation purposes were studied in Kancheepuram region. From the results, it is concluded that there is not much seasonal variation in the drinking water quality. Almost $60 \%$ samples fall under good quality and the remaining locations fall under poor quality for drinking purpose. Also it is clear that the urbanization and industrialization play a major role in the water quality degradation than agricultural dominating areas. From the significance level test, it is concluded that there is no significant difference between pre and post monsoon seasons' water quality parameters; they are equal in both the seasons at $5 \%$ significance level. From an irrigation point of view, it is concluded that there is no seasonal variation in EC. EC is observed as doubtful in almost all the locations and almost similar in the three categories (Industrialized, urbanized and agricultural area). But the SAR varies during pre and post monsoon. According to Aghazadeh and Mogaddam (2010), it is concluded that Kancheepuram, Walajabad, Sriperumbudur, Uthiramerur and Madurantakam blocks are highly affected by Sodium hazard. Due to higher SAR, the infiltration rate of existing soil textures has been severely affected. The ground water quality in urbanized and industrialized areas is highly affected by higher sodium issues. On the whole the water quality is highly affected by industrialized and urbanized areas rather than agricultural area. The disposal, fertilizer use, soil erosion and flooding are the important drivers in 
water quality degradation. Hence, remedial measures like the sewage water from urbanized area and the waste water from industries must be treated as much as possible before it is disposed in the water courses. The legal actions must be taken severely to protect the water quality. Dilution and blending water supply have to be taken in the areas affected by sodium to reduce the sodium hazard through which the cultivable area can get reclaimed for irrigation.

\section{ACKNOWLEDGEMENTS}

The authors would like to acknowledge the Emeritus Professor Dr. R. Sakthivadivel, Centre for Water Resources, Anna University, Chennai for his support in conducting this study and making possible to bring out this article.

\section{References}

Abdullahi A.S, Isa F.I, Ayodele A.S, Peter Z and Muhammad D.B.B, (2010), Investigation of Groundwater quality for Domestic and Irrigation purposes around Gubrunde and Environs, northeastern Nigeria, Journal of American Science, 6(12), 664-672.

Aghazadeh N and Mogaddam A.A (2010), Assessment of GroundWater Quality and its suitability for Drinking and Agricultural Uses in the Oshnavieh Area, Northwest of Iran, Journal of Environmental Protection, 1, 30-40.

Basavaraddi S.B, Kousar H and Puttaiah E.T. (2012), Seasonal variation of groundwater quality and its suitability for drinking in and around Tipur town, Tumkur district, Karnataka, India: a WQI Approach, International Journal of Computational Engineering Research, 2(2), 562-567.

Camberato J. (2001), Irrigation Water Quality, Turfgrass Program, Clemson University, (www.clemson.edu/turfornamental/)

Ghislain T.Y.J., Roger F., Joseph W., Emmanuel E.G. and Ghislain D.M. (2012), Evaluation of Groundwater Suitability for Domestic and Irrigational Purpose: A Case Study from Mingoa River Basin, Yaounde, Cameroon, Journal of Water Resource and Protection, 4, 285-293.

Govindarajan M and Senthilnathan T. (2014), Ground water quality and its health impact analysis in an industrial area, International Journal of Current Microbiology and Applied Sciences, 3(7), 1028-1034.

Haque K.E. (2009), Geochemical assessment of Groundwater in the foothills area of Siliguri, Darjiling district, India, International Journal of Earth Sciences and Engineering, 2(2), 135-144.

Islam M.S and Shamsad S.Z.K.M (2009), Assessment of Irrrigation Water Quality of Bogra district in Bangladesh, Bangladesh Journal of Agricultural Research, 34(4), 597-608.

Joshi D.M., Kumar A. and Agrawal N. (2009), Studies on physicochemical parameters to assess the water quality of river Ganga for drinking purpose in Haridwar district, Rasayan Journal of Chemistry, 2(1), 195-203.

Kalra N., Kumar R., Yadav S.S. and Singh R.T. (2012), Water quality index assessment of groundwater in Koilwar block of Bhojpur (Bihar), Journal of Chemical and Pharmaceutical Research, 4(3), 1782-1786.

Kankal N.C., Indurkar M.M., Gudadhe S.K. and Wate S.R. (2012), Water Quality Index of Surface Water Bodies of Gujarat, India, Asian Journal of Experimental Sciences, 26(1), 39-48.

Karanth K.R. (1987), Groundwater Assessment Development and Management, Tata McGraw-Hill publishers, 217-275.
Manju E.K., George A.V. and Rekha V.B. (2014), A comparative study of Water Quality Index(Wqi) of Vagamon and Peermade sub-watersheds of Meenachil and Pamba river basins of Western Ghats, Kerala, South India, IOSR Journal of Environmental Science, Toxicology and Food Technology, 8(1), 53-58.

Nag S.K. and Das S. (2014), Quality Assessment of Groundwater with special Emphasis on Irrigation and Domestic Suitability in Suri I \&II Blocks, Birbhum District, West Bengal, India, American Journal of Water Resources, 2(4), 81-98.

Omran E.S.E., Ghallab A., Selmy S. and Gad A.A. (2014), Evaluation and Mapping water wells suitability for irrigation using GIS in Darb El-Arbaein, South western desert, Egypt, International Journal of Water Resources and Arid Environments, 3(1), 63-76.

Ramakrishnaiah C.R., Sadashivaiah C. and Ranganna G. (2009), Assessment of Water Quality Index for the Groundwater in Tumkur Taluk, Karnataka State, India, E-Journal of Chemistry, 6(2), 523-530.

Rupal M., Tanushree B. and Sukalyan C. (2012), Quality characterization of Groundwater using Water Quality Index in Surat city, Gujarat, India, International Research Journal of Environmental Sciences, 1(4), 14-23.

Shobana R., Suriyakala K., Sahayaraj P.A., Dharmalingam V. and Soruba R. (2014), Evaluation of water quality of sriperumpudur in Kancheepuram District in Tamilnadu, Der Chemica Sinica, Pelagia Research Library, 5(5), 91-97.

Srikanthan L., Jayaseelan J., Narendran D., Manikandan I. and Sing S.H. (2013), Determination of ground water quality using water quality index in part of Chennai city, Tamilnadu, Indian Journal of Science, 3(8), 81-84.

Tambekar P., Morey P., Batra R.J. and Weginwar R.G. (2012), Quality assessment of drinking water: A case study of Chandrapur district(M.S.), Journal of Chemical and Pharmaceutical Research, 4(5), 2564-2570.

Upadhyay A. and Chandrakala M. (2014), Pre-Monsoon Study of Physico-Chemical Parameters of Hemavathi River, Turuvekere, Karnataka, India, International Journal of Innovative Research in Sciences, Engineering and Technology, 3(9), 15986-15990.

Venkateswaran S. and Vediappan S. (2013), Assessment of Groundwater Quality for Irrigation use and evaluate the feasibility zones through Geospatial technology in Lower Bhavani sub basin, Cauvery river, Tamil Nadu, India, International Journal of Innovative Technology and Exploring Engineering, 3(2), 180-187.

Yogendra K. and Puttaiah E.T. (2008), Determination of Water Quality Index and Suitability of an Urban Water body in Shimoga Town, Karnataka, Proceedings of Taal2007: The $12^{\text {th }}$ World Lake Conference, pp 342-346. 